\title{
A literary work as self-reflection of the author: Why and how it is manifested
}

\author{
IIdha Nurhamidah \\ 2Sugeng Purwanto* \\ 3Nur Ekaningsih \\ ${ }^{1}$ English Literature, Universitas Islam Sultan Agung, Semarang, Indonesia \\ ${ }^{2}$ English Language and Literature, Universitas Stikubank, Semarang, Indonesia \\ ${ }^{3}$ English Education Program, Universitas Islam Sultan Agung, Indonesia
}

*Corresponding Author

Email: drpsugeng@yahoo.com

\begin{abstract}
Anyone on earth may at one time or another reflects him or herself in a way he or she feels comfortable-be it as simple as writing up a phrase "Go to Hell with Communism!" on a wall of an old building. In this respect, he or she has reflected him or herself that he or she does not agree with the ideology of communism. The current study investigated to justify that literary works reflect the 'selves' of the authors in one or more possible ways. A poet may, to reflect him or herself, be characterized as employing particular styles or diction. A novelist may try to involve in one of the characters he or she has developed in order to reflect him or herself. In this study, a novel entitled "Pride and Prejudice" by Jane Austen (1813) was investigated to justify that the author (Austen) reflected herself in one of the characters in the novel. The findings reveal that Austen tried to manifest herself in one of the characters called 'Elizabeth Bennet' in three different ways: (1) how she behaved in her family (loving all family members, especially being close to her father), (2) how she spent most of the time-reading to broaden the horizon of thinking. As a result, she could (3) skillfully negotiate with other people through their positive sides. The study concludes that everyone, of whatever professions he or she has, will reflect him or herself in a way he or she may not realize.
\end{abstract}

Keywords: literary work; self-reflection; novelist; character

$\begin{array}{llll}\text { Received: } & \text { Revised: } & \text { Accepted: } & \text { Published: } \\ \text { 2 June 2019 } & \text { 27 August 2019 } & \text { 27 August 2019 } & \text { 31 August } 2019\end{array}$

\section{INTRODUCTION}

On a careful scrutiny of any literary work, an individual may jump to a relatively correct assumption of the author. with respect to his or her 'selves' in the sense that there are features in the literary work in question that the author manifests him or herself (Purwanto \& Nurhamidah, 2018). Actually everyone without exception will reflect him or herself in many different ways, depending on the profession, the level of education, the political views, to 
Nurhamidah, Purwanto, Ekaningsih, EduLite: Journal of English Education, Literature, and Culture Vol.4, No.2, August 2019, 194-203 DOI: http://dx.doi.org/10.30659/e.4.2.194-203

mention only few. A medical practitioner, for example, in his or her later age upon retirement from his or her formal office in a particular hospital, may still want to offer medical helps to anyone in need without expecting much of financial gains (Lynn \& Adamson, 2003). He or she feels relieved if he or she can be meaningful to others. Thus, his or her self-orientation is more to social than financial domain. It is all possible since he or she has fully actualized him or herself as a medical practitioner.

A novelist may manifest him or herself in his or her masterpiece. He or she is representation of the main character in the novel he or she is mostly proud of. A shadow puppeteer may become representation of one or several of the puppets with which he is very knowledgeable. Ki Nartosabdo, for instance, actualized himself in 3 (three) characters (of puppets), namely Karno, Salya and Kresna. He was very much dissolved when he was playing any of the three characters. A great poet of Java, Ranggawarsita, can also be assumed as actualizing himself in a poem entitled 'Serat Kalatidha' as it is the most famous poem, depicting the crazy age.

Studies on self-reflection-involvement of an author in the characterization-have been conducted with different purposes. Muzakki investigated the nature of a literary work, coming up with a question: Karya Sastra, Mimesis, Realitas atau Mitos (Literary Work, Mimeses, Reality or Myth). In this respect, it is argued that the imagery world consists of ideas and language employed in a literary work. The two elements (ideas and language) surely derive from the inner parts (imagery repertoire) of the author (Muzakki, 2011). However, Muzakki continues to argue that a literary work must be logically presented as it may take place in reality or at least it is a reflection of life.

Another study claimed that self-reflection is a review of experience used as a reference to the present decision (Palomäki, Laakasuo, \& Salmela, 2013). It seems to describe him or herself in a way he or she describes the characters in a literary work into which he or she is deeply sucked. It has a power to stimulate an individual's awareness of his or her emotion in a better way with which to grow emotionally better with respect to better self-development. It is claimed that self-reflecting is simply a skill that can be trained by means of new angles of manifestation. By 'trained' she implies that a professional author may change or switch his or her manifestation from one character to another within one or more literary works. It is easy for such an author to write a fancy novel in which he is involved in the story even though he is actually very sad. He somehow manages to remain 'fancy' in the story. Such an author has multiple personalities. In the morning, he has to give a eulogy on the death of a friend in which he has to appear sad. But in the afternoon, he has to sing a song in a friend's wedding party in which he shall appear joyful.

As argued above that a literary work is a reflection of life (sometimes of the author), a novel can be put on a wide screen (filmed), so can a poem or even an epic (Cartmell \& Whelehan, 2013). An example of an epic to be filmed or to be rewritten in different forms to facilitate comprehension is the epics of Baratayudha and Ramayana-both are imaginative but can be made as if it were real by adopting names of places and or individuals reflecting the local people (India origin). In this respect, India people especially under Hindu 
religion are reflected in these sacred holy epics. The great epic of Mahabarata has also been actualized in Java as some places or streets are named after the names of the Mahabarata characters. Thus, actualization is to make 'imagery' become 'reality'.

It has been somehow touched upon that everyone reflects him or herself differently-extremely speaking as exemplified in the abstract, an individual who wrote "Go to Hell with Communism!" can be categorized as reflecting 'self' in disagreement with communist ideology. People of the have reflect differently from those of the poor (Goleman, 2013). In this respect, it is not wise to judge people by their look. There has, nowadays, a lot of honey wrapped in simple packaging. Conversely, there has, also, poison wrapped in luxurious packaging to represent hoaxes (Shariff \& Gouin, 2005). This, at the same time, justifies a famous and vivid saying that the taste of the pudding is the eating. One never knows something until he or she is involved in this 'something'.

The underlying issue of the current study is that, to the best of the researchers' knowledge, nowadays Austen's Pride and Prejudice has never been researched in terms of how the author (Jane Austen) reflected herself in one of the character in a way as if she wanted to tell the readers how she viewed the world through her style of characterization to reflect who really Jane Austen was-her behavior, habits and ways of thinking. Many studies on novels, of course, have been conducted by scholars employing the so called intrinsic and extrinsic approaches to find out the characters, plot and setting apart from extrinsically relating the phenomena in the novel to the outer world of other disciplines, such as psychology, sociology to represent the social condition when the novel was written or at what social conditions a particular author was aiming (Paris, 2017). The case of Jane Austen's Pride and Prejudice has been analyzed from different points of view, resulting in different interpretations in different studies by different literary analysts. However, as previously stated, no (few) literary analysis dealt with how Jane Austen actualized herself in her masterpiece.

Pertinent to the above background, there is only one research question of the current study that can be formulated, namely "What linguistic evidence can be presented to highlight Austen's self-reflection in one of the characters in Pride and Prejudice?"

The answer to the above research question is urgently required or demanded as it would open up the minds of the common people that selfreflection may be realized in different ways and different intensity. A good and successful self-reflection may create self-features that tend to make the owner become 'legendary' (Eisner, 2008). Muhammad Ali becomes legendary because of his success in creating self-reflection as the big-mouth and dancing boxer (Saeed, 2002). Similarly, Suharto (the second president of Indonesia) was famous for being characterized to reflect himself as a General who could order his troops with a single lift of his forefinger tip. He managed to reflect himself during his 32-year regime as such (Bunnell \& Ann Miller, 2011). Still another example is Bruce Lee, a legendary Kungfu fighter (a movie star) who died in a mysterious way despite his fully trained body, and fast punches and kicks(Frantzis, 2008).

In terms of theories, identifying linguistic evidence pertinent to selfreflection is somehow similar to characterization in a structural or intrinsic 
Nurhamidah, Purwanto, Ekaningsih, EduLite: Journal of English Education, Literature, and Culture Vol.4, No.2, August 2019, 194-203 DOI: http://dx.doi.org/10.30659/e.4.2.194-203

approach to an analysis of literary works. A character in a novel is investigated through careful reading between lines the description about the character in question, in order to come up with a clear picture of his or her physical and mental behaviours or attributes (Koopman \& Hakemulder, 2015).

Physical behaviour includes how he or she represents him or herself toward other people and nature. Meanwhile mental behaviour refers to how he or she thinks about other people and nature(Suddendorf \& Corballis, 2007). This is, in other words, how he or she interacts with other people or nature or the environment. Dialogues in the novel may also give clues to the characteristics of an individual. In self-reflection of an author with respect to his or her literary work(s), however, not only does it involve characterization but also the biography of the author in question. Only by making a comparison between the biographies (of the author) with characterization would identifying self-reflection located within a particular literary work successfully be undertaken (Ash \& Titchener, 2015).

\section{METHOD}

The present study belongs to a library research in which the researcher(s), in the process of resolving or answering the research questions, relied heavily on the information from the object itself (novel) supported by any information taken from various relevant resources (Liamputtong \& Ezzy, 2005). The object of the current study is a novel entitled "Pride and Prejudice" by Jane Austen (Austen, 2001) whose assumed self-reflection was analyzed projecting her biography and characterization of an assumed character to find out whether they were matched to one another.

Included in the research procedures were (1) having full comprehension about the novel on the basis of which (2) the object (novel) could be scrutinized in line with the research question, (3) justifying whether Jane Austen as the author of 'Pride and Prejudice' reflected herself in any of the intrinsic elements of the novel. Linguistic evidences (relevant quotations from the novel) were presented and described in support of the findings

\section{RESULTS AND DISCUSSION}

As previously stated, this study took up Jane Austen as a sole subject of investigation with respect to her self-reflection in her 'Pride and Prejudice' (Austen, 2001). She is a great female author of all times despite her Georgian era of authorship. Best known for her social commentary through three novels 'Sense and Sensibility' (Austen, 2004), 'Pride and Prejudice' (Austen, 2001), and 'Emma' (Austen, 2018), that managed to bring her to fame around the world.

Biographically speaking, Austen was born on December 16, 1775 as the seventh child and second daughter of Cassandra and George Austen. She lived within close-knit family of Anglican tradition, resulting in her closeness to her father and older sister. This is a real manifestation of her attitude toward seniors (Hollingsworth, 2017). She was grown up in an educated family as her father was Oxford educated rector for a nearby Anglican parish (Collins, 2003). This made her interested in reading a variety of books on different disciplines which at the same time encouraged her to be a productive author (novelist) with special products of various societal outlooks. She can be said as one of 
the most prominent social critics in her era through her novels (Jones, 2009). Many individuals might have been emotionally touched by the existence of her novels possibly resulting in the change of public policies toward the betterment of the powerless but without degrading the powerful.

Based on the snapshot of her biography, it is possible to match her in her self-reflection as found in 'Pride and Prejudice' as a cross-reference of justification-as to how it is manifested.

On closer scrutiny, it is assumed that Jane Austen reflected herself in her 'Pride and Prejudice' in a personified character called 'Elizabeth Bennet' in three identified characteristics (Newton, 1978). Described below is a step-bystep description of how she manifested herself in the characters she had developed as her self-actualization.

First of all, Jane Austen loved all the family members as she was grown up in close-knit family. Within the family circle, the members were hand in hand to help one another in case of problems (Austen, 2011). This is in line with what she reflected herself in the environmental characteristics of 'Elizabeth Bennet' as illustrated below:

Elizabeth-one of the characters in Jane Austen's Pride and Prejudice; and the one Jane Austen reflected herself-loves and cares for her family members. When, for example, she heard that her elder sister, Jane was sick, she worried about her condition. In this case, although her mother did not let her use the carriage, she undoubtedly went to visit her sister on foot, risking her petticoat getting muddy. In support of her struggle, Mr. Bingley's sisters, quoted as saying, "...Very nonsensical to come at all! Why must she be scampering about the country, only because her sister had a cold?" (Austen, 2001) In this respect, it is clear that Elizabeth worried so much about her sister despite the fact that her sister just had a cold, the slightest sickness of people of all time. This is a reflection of Jane Austen's personality as she was grown-as stated above-in close-knit family, implying how members of the family shared mutual love and understanding among one another. In such a family, hurting one member truly means hurting the others. One smiles, the others feel the happiness.

In addition, when Elizabeth's youngest sister, Lydia stupidly escaped with a gentleman called Mr. Wickham-something thought of as thereby degrading the family social status-Elizabeth worried much about the situation. She wanted to go home to take care of the family problem caused by her sister's escape. It was actually Mr. Darcy, a powerful figure who settled everything in a barter of love (Austen, 2001). This is another way Jane Austen reflected herself in Pride and Prejudice to take up Elizabeth's personal characteristics. Had she been put in the same position as Elizabeth's, she would have done the same to save her family disharmony. Unfortunately, Jane Austen's family did not experience exactly the same things in her novel.

Another issue of Elizabeth as Jane Austen's made-up character is that she is very much closely related to her father and her elder sister (Tucker, 1995), as compared with the rest of the family members, her father (Mr. Bennet) quoted as saying, "...though I must throw in a good word for my little Lizzy." (Austen, 2001). The use of "Little Lizzy as a nick name to Elizabeth clearly showed a very close relation. Similarly, Jane Austen was so much close to her father, as Oxford educated rector for a nearby Anglican parish, that she 
Nurhamidah, Purwanto, Ekaningsih, EduLite: Journal of English Education, Literature, and Culture Vol.4, No.2, August 2019, 194-203 DOI: http://dx.doi.org/10.30659/e.4.2.194-203

were as if locked in her father's library-symbolizing closeness to her fatheronly to read a variety of books to widen her horizon of thinking.

Secondly, Jane Austen loved reading very much (Grundy, 2011). This is also reflected in Elizabeth's love of reading. Mr. Hurst, the husband of Luisa (whose name was Miss Bingley) quoted as asking, "Do you prefer reading to cards... This is rather singular." He looked at her with big surprise that Elizabeth refused the invitation to play card and like to read book better. Miss Caroline Bingley confirmed his astonishment by elaborating "Miss Eliza Bennet ... despises cards. She is a great reader, and has no pleasure in anything else." (Austen, 2001). Such as habit is not bad at all since reading is the mother of learning. Reading may influence the way of thinking and behaving and thus it is closely related to attitude. The essence (result) of reading is stored in the braid and can be retrieved for future use, such as in writing or speaking.

Finally, it is clear that reading for Elizabeth has resulted in her ability to see other people from the positive angles of look. In this respect, she was able to negotiate an issue by convincing other people about her argument (Halsey, 2013). She was just like a lady who managed to behave socially acceptable among all walks of life-never would, in any social encounter, she disgrace other people. In short, she was just a perfect woman on earth. It was skillfully described in Pride and Prejudice that:

Elizabeth, still more affected, was earnest and solemn in her reply; and at length, by repeated assurances that Mr. Darcy was really the object of her choice, by explaining the gradual change which her estimation of him had undergone, relating her absolute certainty that his affection was not the work of a day, but had stood the test of many months' suspense, and enumerating with energy all his good qualities, she did conquer her father's incredulity, and reconcile him to the match (Austen, 2001).

From the above quotation, it is clear that Elizabeth was described as a very talented woman who specialized in presenting moderate arguments against other people by constant reassurance of her choice of a man to be her future husband. In response to her father's stance-_... We all know him to be a proud, unpleasant sort of man; but this would be nothing if you really liked him." (Austen, 2001) — toward Mr. Darcy, she just said, "I do, I do... I love him. Indeed he has no improper pride. He is perfectly amiable. You do not know what he really is; then pray do not pain me by speaking of him in such terms." (Austen, 2001). This shows that Elizabeth was tactful in replying her father's argument. She managed to convince that Mr. Darcy was correctly chosen as her future husband. In short, she was a good negotiator as she has learned how to manipulate words in her arguments.

Likewise, when Elizabeth convinced her sister, Jane, over her engagement to Mr. Darcy, she showed her talent of negotiation. At first Jane did not believe that Elizabeth was in serious relationship to Mr. Darcy as she knew how much Elizabeth was in disagreement with him; Jane quoted as saying, "You are joking, Lizzy. This cannot be!-engaged to Mr. Darcy! No, no, you shall not deceive me. I know it to be impossible." (Austen, 2001). In this respect, Elizabeth managed to assure Jane by saying: 
You know nothing of the matter. That is all to be forgot. Perhaps I did not always love him so well as I do now. But in such cases as these, a good memory is unpardonable. This is the last time I shall ever remember it myself (Austen, 2001).

From the above quotation, it is arguably true that Elizabeth was skillfully presenting arguments in order to convince her sister. It can be seen from the style of speaking. Such a style only belongs to highly-talented rhetorician, someone who was able to engineer the use of lexico-grammar to create such convincing utterances.

With respect to Jane Austen as the author of Pride and Prejudice, it can be undoubtedly argued that she revealed herself personally as Elizabeth in Pride and Prejudice. So prominently was Jane Austen as a novelist of all ages that she managed to produce 'Jane Austen in quotes from her published novels: 30 tips for a successful life' (Bausells, 2014). Had she not been such a graceful and wise novelist, wouldn't there have been so many moral tips that could be generated from her literary works. She had managed to offer moral teachings on love, marriage, women and men, life, art-to mention just few out of 30 quotes.

However, Jane Austen has published a number of best-seller novels, of which Pride and prejudice is one under the current study to justify that she has manifested herself in one of the characters in the novel as Elizabeth. She, as if, described herself in full accounts. Not only in Pride and Prejudice were her personalities manifested-in the researchers' personal assumption-but also in other literary works of hers (Ash \& Titchener, 2015).

With her extraordinary skills of writing, Jane Austen managed to produce quite a number of novels, depicting the social lives of her time. Therefore, it is arguably true that she belongs to one of successful social critics through literary works. In her era, literary works served as the best social critics toward unfair treatments of different classes of people (Jones, 2009). Shealong with other female novelists-also contributes a lot in the struggle of feminism, racism and other social discriminations. Many of Jane Austen's thoughts on love, relationship, clothes and even the joys of nature are extraordinarily relevant to modern life, as shown in the 239th anniversary. Therefore, it is arguably true and convincing that Jane Austen-as a result of her vast reading-is fully-fledged with respect to the up and down of life to positively see social problems, and by all means able to view people's positive sides, thereby hedging the negative ones for better social touches. She is, in short, a good negotiator and tactful enough to argue positively with other people (Newton, 1978).

Thus, it can be justified that Elizabeth (the character) in Pride and Prejudice (the novel) is a representation of Jane Austen (the author). As a skillful author, Jane Austen may be represented differently in different literary works of hers. The most important thing is that the representation, whatever it may look like, will not be far from her basic characteristics that she has developed throughout her lifetime. She remains outstanding among other authors of her time. 
Nurhamidah, Purwanto, Ekaningsih, EduLite: Journal of English Education, Literature, and Culture Vol.4, No.2, August 2019, 194-203 DOI: http://dx.doi.org/10.30659/e.4.2.194-203

\section{CONCLUSION}

In general, it is arguably true that self-reflection is normally undertaken by any individual in line with what he or she does to make a living. Besides, selfreflections may also be influenced be the level of education, the friends to get along with, the kinds of books to read, the film to watch, and the religious and political stances to adopt. In short, self-reflection represents both physical and mental undertakings in response to both human and non-human environmental phenomena. A good professor in a university or college may actualize him or herself in a way he or she feels comfortable with. The goal of his or her life is, for example, not to accumulate wealth, but to disseminate knowledge. Another professor is different. He or she may still collect money without social mercy to other people around. He or she only wrote few books (but of high prices). He or she was seldom invited to give public speeches as the fee was too high.

Back to the main concluding remarks, in her literary work entitled 'Pride and Prejudice', Jane Austen skillfully reflected herself in one of the characters called 'Elizabeth Bennet' as an individual who loved all the family members and was relatively close to her father and elder sister. She loved reading books of various disciplines of science to broaden her horizon of thinking. As a result, on reading Jane Austen's literary works, the readers might be able to locate which character she reflected herself.

In response to the overall data analysis, the researcher(s) would like to highlight the following issues of interest with respect to self-reflection:

1. Never judge other people from their outer looks. It is possible that they try to hide their real beings.

2. Never underestimate the self-reflections of other individuals. They may self-reflect differently as human-beings were created differently in order to help one another.

3. Always take a look at other people from the positive sides as the realities of others are as deep as the depth of the sea.

4. Conduct similar studies from different angles of look to find out whether other great authors have the same self-reflections as Austen's. 


\section{REFERENCES}

Ash, R., \& Titchener, F. B. (2015). Fame and Infamy: Characterization in Greek and Roman Biography and Historiography. Oxford University Press.

Austen, J. (2001). Pride and prejudice. Broadview Press.

Austen, J. (2004). Sense and sensibility. OUP Oxford.

Austen, J. (2011). Jane Austen's letters. Oxford University Press.

Austen, J. (2018). Emma. In Medicine and Literature, Volume Two (pp. 19-34). CRC Press.

Bausells, M. (2014). Jane Austen in quotes: 30 tips for a successful life.

Bunnell, T., \& Ann Miller, M. (2011). Jakarta in post-Suharto Indonesia: decentralisation, neo-liberalism and global city aspiration. Space and Polity, 15(1), 35-48.

Cartmell, D., \& Whelehan, I. (2013). Adaptations: from text to screen, screen to text. Routledge.

Collins, I. (2003). Jane Austen and the Clergy. A\&C Black.

Eisner, W. (2008). Comics and sequential art: Principles and practices from the legendary cartoonist. WW Norton \& Company.

Frantzis, B. (2008). The chi revolution: Harnessing the healing power of your life force. Blue Snake Books.

Goleman, D. (2013). Rich people just care less. New York Times, 5.

Grundy, I. (2011). Jane Austen and literary traditions. The Cambridge Companion to Jane Austen, 2, 192-214.

Halsey, K. (2013). Jane Austen and Her Readers, 1786-1945. Anthem Press.

Hollingsworth, P. (2017). Spirituality of Jane Austen. Lion Books.

Jones, H. (2009). Jane Austen and marriage. Bloomsbury Publishing.

Koopman, E. M. E., \& Hakemulder, F. (2015). Effects of literature on empathy and self-reflection: A theoretical-empirical framework. Journal of Literary Theory, 9(1), 79-111.

Liamputtong, P., \& Ezzy, D. (2005). Qualitative research methods (Vol. 2). Oxford university press Melbourne.

Lynn, J., \& Adamson, D. M. (2003). Living well at the end of life. Adapting health care to serious chronic illness in old age. RAND CORP SANTA MONICA CA.

Muzakki, A. (2011). Karya sastra: mimesis, realitas atau mitos? LiNGUA: Jurnal Ilmu Bahasa Dan Sastra, 2(1).

Newton, J. L. (1978). "Pride and Prejudice": Power, Fantasy, and Subversion in Jane Austen. Feminist Studies, 4(1), 27-42.

Palomäki, J., Laakasuo, M., \& Salmela, M. (2013). “Don't Worry, It's Just Poker!"-Experience, Self-Rumination and Self-Reflection as Determinants of Decision-Making in On-Line Poker. Journal of Gambling Studies, 29(3), 
Nurhamidah, Purwanto, Ekaningsih, EduLite: Journal of English Education, Literature, and Culture Vol.4, No.2, August 2019, 194-203 DOI: http://dx.doi.org/10.30659/e.4.2.194-203

491-505.

Paris, B. J. (2017). Character and conflict in Jane Austen's novels: a psychological approach. Routledge.

Purwanto, S., \& Nurhamidah, I. (2018). First love simplicity: A systemicfunctional perspective study of Karina Del Campo's Do You Remember Our Love? EduLite: Journal of English Education, Literature and Culture, 3(2), 161-172.

Saeed, A. (2002). What's in a name? Muhammad Ali and the politics of cultural identity. Sport in Society, 5(3), 52-72.

Shariff, S., \& Gouin, R. (2005). Cyber-dilemmas: Gendered hierarchies, free expression and cyber-safety in schools. In Oxford Internet Institute conference at Oxford University, Oxford, UK. Retrieved November (Vol. 20, pp. 147-154).

Suddendorf, T., \& Corballis, M. C. (2007). The evolution of foresight: What is mental time travel, and is it unique to humans? Behavioral and Brain Sciences, 30(3), 299-313.

Tucker, G. H. (1995). Jane Austen the Woman: Some Biographical Insights. Palgrave Macmillan. 